\title{
ESTABLISHMENT OF A LIBRARY TO IMPROVE THE QUALITY OF HUMAN RESOURCES IN APUAI VILLAGE
}

\section{JISCOS \\ 01, 2}

Received, October 2021

Revised,

November 2021

December 2021

Accepted,

December 2021

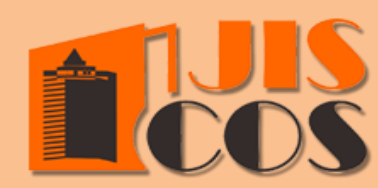

\section{CORRESPONDING AUTHOR}

Author's Name:

Surti

Institution: Univ. Achmad Yani Banjarmasin

E-mail: surtisufyan14@gmail.com

\author{
Surti $^{1}$, Gusti Marliani ${ }^{2}$ \\ ${ }^{1}$ Universitas Achmad Yani Banjarmasin \\ ${ }^{2}$ Universitas Achmad Yani Banjarmasin
}

\begin{abstract}
Besides formal education such as schools and special training, education can also be obtained through libraries and other media such as the internet or television to access knowledge and information. Apuai Village, Aranio District, Banjar Regency is an underdeveloped village where people challenging to access the internet or telephone signals, and access roads to and from the village are not accessible. This condition is a significant obstacle to transferring information and knowledge from outside. To meet the community's needs in obtaining knowledge, the community service team took the initiative to establish the Apuai Village library. The hope is that the existence of this library can help the community, especially school children in the village, to have insight into creative thinking, cultivate spirituality, foster interest in reading, increase the efficiency and effectiveness of learning in the library. It is also hoped to increase entrepreneurship awareness for the readers for the local community with a low level of education. This community service activity also contains counseling to increase interest in reading. By diligently reading, people will find new knowledge to improve their ability to manage their natural and human potential. As a collection material, our library also provides books related to products and books on marketing strategies and product packaging to increase competitiveness. So far, the community can process natural products into something with better power. They also have difficulty in terms of packaging and marketing. It is because of the difficulty of access to information on attractive marketing and packaging techniques due to the problem of access to transportation, information, and telecommunications in this village.
\end{abstract}

Keywords: Education, Village Library, Literature Study, Apuai Village, Welfare

DOI: http://dx.doi.org/10.21776/jiscos.01.1.01

Cite (Harvard):

Surti, Gusti Marliani. (2022). Establishment of a Library to Improve the Quality of Human Resources in Apuai Village. Journal of Interdisciplinary Socio-Economic and Community Study, Volume 01, Number 2, Pages 41-47. Universitas Brawijaya. DOI: http://dx.doi.org/10.21776/jiscos.01.1.01

Indexed in

Google 


\section{INTRODUCTION}

Education is an aspect that has the most critical role in improving the quality of human resources. The higher a person's education, the higher the quality of his life. The high quality of life of a nation shows the increased welfare of the country. Education can be done through formal education such as school and informal and nonformal education. Lasa (2007) explains that the library has several functions, such as media of education, a place to learn, simple research, utilization of information technology, alternative classes, and sources of information.

Meanwhile, Yusup (2005) states that the library has a meaning as a place where there are activities for collecting, processing. It includes disseminating (services) all kinds of information, both printed and recorded in various media such as books, magazines, newspapers, films, cassettes, tape recorder, video, computer, etc. All collections of information sources are arranged according to a specific system and are used for learning purposes through reading and seeking information for all people who need it.

The community can find one informal training through libraries or other media where people get knowledge and information other than through school. Libraries as a means of learning are essential and even mandatory to be held in every corner of this country, especially for areas that have difficulty getting access to electronic media, which today are other media for obtaining knowledge, information, and learning facilities. This condition is reflected in Apuai Village, Aranio District, Banjar Regency, where they have difficulty accessing the internet or telephone signals, which become essential for most people in this part of the world.

Overall, Apuai village is very far from progress because of the lack of adequate facilities and infrastructure, for facilities in the form of electricity, signal, and the internet is challenging to obtain. Villagers, on average has low education and part of the population is still large who are illiterate because, in this village, there is only one school, namely Madrasah Ibtidayah Manbaul Ulum, which is equivalent to Elementary School. Children in the Apuai Village have not received adequate education due to lack of school to a higher level and limited educational books. To continue their education, they must be willing to cross the lake to go to school in the city; the school distance is very far is one of the factors that some people in this village break up school because of insufficient funds. Therefore, the people in this village experience educational backwardness and lack of knowledge of information and developments of the times. The people of Apuai Village, on average, make a living as rice farmers, and economically still in the lower middle level with income uncertain and the average income is around one million five hundred thousand rupiahs with several dependents 2-4 people in one family.

According to Darmono (2013), the notion of village libraries has four keywords about village libraries, namely: (1) community-based libraries, (2) functioning as learning facilities and media, (3) to improve and support community education, and (4) are part of the community integral development. Studies on the benefits of other village libraries have been discussed by Saepuddin (2017) in his article entitled "Practical Values of Village Libraries and Community Libraries in West Java." Among the benefits or use values of existing libraries in an area (region), public, school, university, and particular/institutional libraries are theoretical and practical. First, public libraries, for example, refer to the functions inherently owned by libraries, such as informative, educational, recreational, and research functions. These functions can work if all types of collections owned by the library can be optimally utilized by people who need information and sources of information according to their interests.

Meanwhile, other use-values are related to the library's function as a center for information resources in the village and the library. It functions as a center for reference sources for the community in general. Other types of libraries also have relatively similar values as those of public libraries. Meanwhile, practical use-value is directly related to its role or function that can instantly benefit the community related to their work or profession. 
Community service related to this has been carried out, such as Rohman, Erwina, and Lusiana (2018). They educate the managers of village libraries and community reading parks (TBM) about changing concepts and strategies for serving the community. The village library and TBM are a means of reading and can be optimized as a learning tool to support community empowerment programs. Meanwhile, the community service carried out by Pandapotan (2017), namely the development of the Literacy Village in Swimming Village, Deli Serdang Regency, in collaboration with various partners, carried out a series of socialization and roadshows to 5 elementary schools as well as non-formal education for school-age children, adolescents, and the general public by developing learning centers and reading gardens. Kurnianingsih et al. (2020) have also carried out a similar community service program, namely the establishment of a village library to improve the quality of human resources by providing information sources both printed and electronically managed by the library utilizing information technology, as well as training in information technology-based library management for library managers.

Based on the above conditions, this community service program from Achmad Yani Banjarmasin University took the initiative to establish a library as an educational facility to meet the community's educational needs in Apuai Village. In addition, it is hoped that this library can help the community, especially school children in the village, to have insight that thinks creatively, fosters spirituality, fosters interest in reading, increases efficiency and effectiveness of learning in the library. In addition, the reason is that there are still many people in Apuai Village with low welfare levels, it is hoped that this library can be used to add references to increase knowledge and experience.

The position of community service activities in Apuai Village is to assist the community and school-age children in meeting their needs for the availability of references and information that cannot be obtained at school or in the village. Apuai Village does not yet have a single library, village, or school library, plus there is no internet network facility, and road access is quite tricky. So, that with the existence of this library, the community, and school-age children will more easily access knowledge and information through books in the library. Suppose previous studies mostly only relied on providing counseling about reading interest. In that case, this study educates about the importance of reading to expand experience and knowledge and offers media to increase reading interest.

\section{METHOD}

Apuai Village area of $76 \mathrm{~km}^{2}$ with a total population of 455 people in 2019 (BPS Kabupaten Banjar, 2019). Apuai Village is approximately $110 \mathrm{~km}$ from downtown Banjarmasin as the capital of South Kalimantan; it takes around 4 hours of travel to Apuai Village. Two alternative roads can be taken; first, using the road but the risk of damaged and winding roads. Then the second alternative is to go to the pier for 2 hours and then board the ship, and it takes more than 2 hours from the dock to Apuai Village.

The people of Apuai Village, on average, are farmers because the potential for rice, rubber, and horticultural crops is quite well developed in the village. This and the lake's potential area are suitable for freshwater fish farming using cages. Most of the people in Apuai village have primary education because it is difficult to continue their education. The nearest junior high school is in the next village, and you have to take a boat to get there. (Tribunbanjar, 2020).

In response, the team used a method approach through community education, namely, establishing a village library with textbooks for school-age children and literature books. According to the village's potential and diversification, it is possible to increase interest in reading and improve the welfare of rural communities through literature studies. This service aims to teach the community the importance of education. The data collection used in supporting this service is Literature Review, Observation, Documentation, and Interview. This activity data is village 
characteristic data that is used as a basis for selection due to the lack of information and references that can be used by the Apuai Village community, especially school-age children.

Activities are carried out through 4 stages, starting from planning, preparation, program socialization, implementation of activities. This service is in Apuai Village, located on Jl. Ir. PM Noor, Apuai Village, Aranio District, Banjar Regency, South Kalimantan Province. This service lasts for three months, from November 2019 to January 2020. In this activity, the team invited the village government to manage the village library and continue to motivate its citizens to love reading and use the library according to the expectations of this activity.

To resolve the priority issues that have been described before, the Plan and Design of the Community Service Program carried out from November 2019 to March 2020 are as follows:

1) Research and Field Survey Phase, where the team takes an inventory of the number of villages targeted and conducts research in several villages.

2) The planning stage is carried out after finding the village target, then forming and debriefing the team, and then compiling proposals submitted to various targeted parties as donors in November 2019.

3) Socializing the program to the village government and stating the aims and objectives of implementing the community service program in the village concerned will be carried out in November 2019.

4) Collecting donations in the form of books, both new and used, but still relevant and worth reading. Related parties can also provide financial assistance that will be used to purchase equipment and equipment in carrying out activities from November 2019 to December 2020.

5) The implementation of this activity includes establishing a library by the team located in one of the equivalent elementary schools in the village. It has one room that does not yet have a function; the group arranges items such as cupboards, books, "lesehan" tables for reading, carpets, library cleaning equipment, and installation of library signs.
This activity was carried out on December 27, 2019.

6) Inauguration of the opening of the village library, which was named "Library Manbaul Ulum." This followed by providing counseling and education to school-age children to increase their reading interest in the library. Then in a different place, namely at the Apuai Village Office, providing counseling to the community about the role of literary studies to the local community in improving welfare. The inauguration and counseling were carried out by a team divided into two on December 28, 2019.

\section{RESULTS AND DISCUSSION}

During the implementation of community service activities, the results achieved can be seen from the suitability of the type and number of outputs. It has been produced to the overall target of the action in implementing the activities that have been carried out. Of course, there are changes in activities and additions to activities that have been carried out coordinated with the relevant parties.

In the early stages of program implementation, a team from Achmad Yani University Banjarmasin conducted an inventory of several villages that would be targeted. The team was divided into several people tasked with conducting preliminary research and surveys to determine which villages would be selected for this activity. The results of the study and deliberation finally chose Apuai Village in Aranio District, Banjar Regency, as the target village. The reason for selecting this village is that it is still difficult to access information in this village. After all, telephone and internet signals are challenging to obtain, and road access is not easy to get to this place. The establishment of a village library is a consideration. It is crucial to open public knowledge, especially school-age children.

Then the team begins to develop proposals to be submitted to the target donors that the team has set in the meeting. Then make posters, pamphlets, and brochures to raise funds and aid books, both new and used but worthy of reading by the general public. All forms of these 
campaigns are channeled directly and through social media. As a result of this stage, the team collected around 6 million rupiahs and more than 1,000 copies of new and used books.

The next stage is the socialization of activities to the Apuai Village Government. This socialization activity aims to explain to the village government the aims and objectives of carrying out this community service activity. After socialization and coordination with the village head, the village government will continue the socialization to community leaders to be conveyed to the community regarding this activity. As a result of this socialization, the Apuai Village Government will provide a room for a library that will borrow a place at the Elementary School level Madrasah Ibtidaiyah named Manbaul Ulum as a library room. Then for time efficiency, the counseling will be divided into two locations: the library room later for school-age children and the general public at the village head office. Furthermore, the results of this socialization also decided that the Village Government would act as the Karang Taruna fostered library manager.

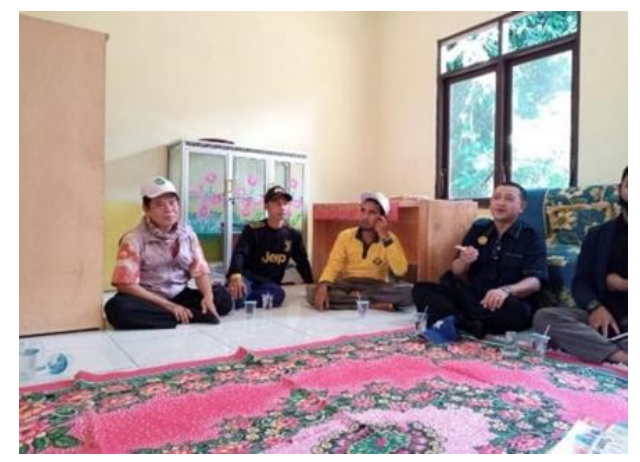

Source: Author Documentation, 2021

Figure 1

Dissemination of the activity plan to the village government

The next stage is the implementation of activities that last for two days. The first day the team cleaned the room used as a library, then arranged the cupboards, tables, and books and put up the library's nameplate. The next day, the head of the village inaugurated the opening of the library, accompanied by the head of the Madrasah Ibtidayah Mambaul Ulum and several community leaders.
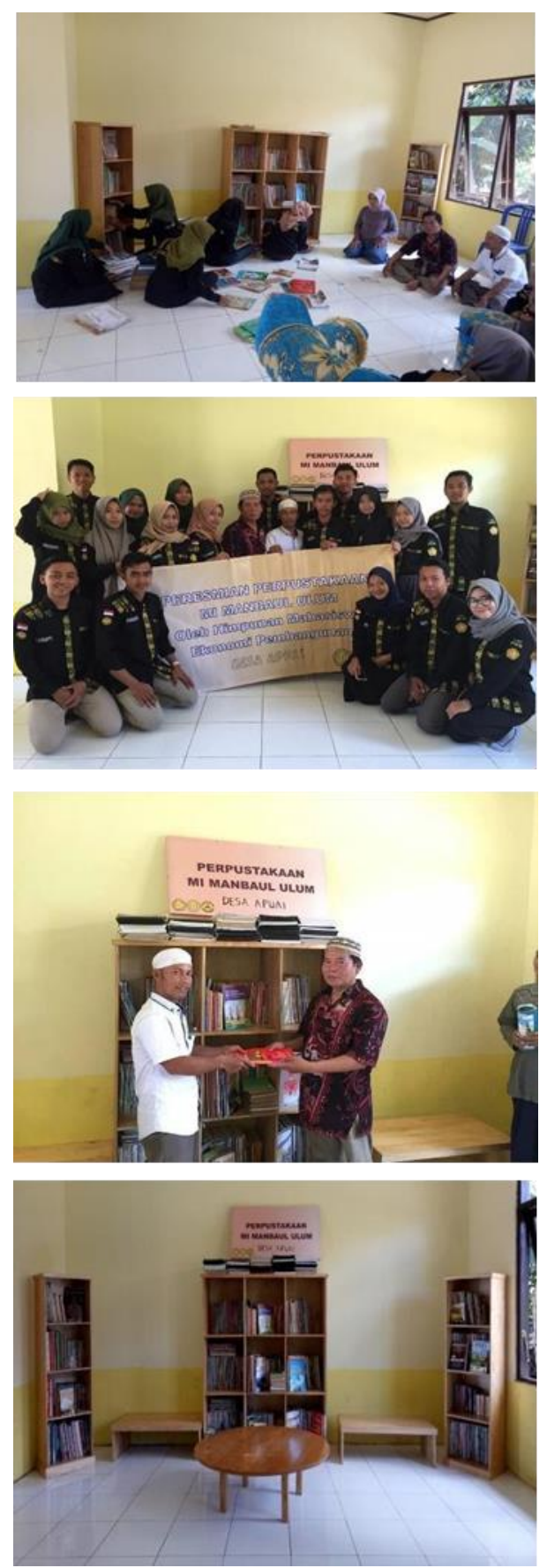

Source: Author Documentation, 2021

Figure 2

Prepare and Inauguration Of The Library Establishment

After the official opening, the team was divided into two groups. The first group provides counseling and education to school-age children about the importance of libraries to increase interest in reading. Meanwhile, the second group provided counseling to the general public of Apuai Village about the role of literary studies to improve community welfare. 

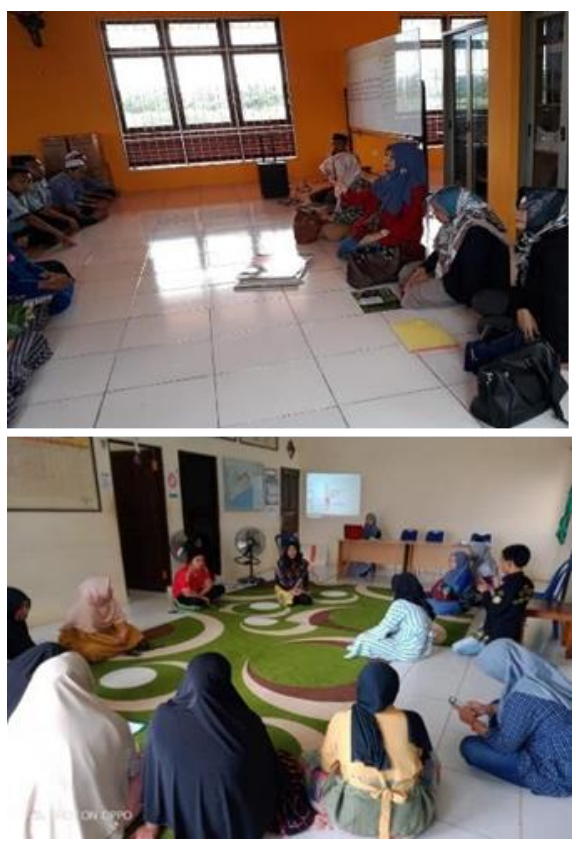

Source: Author Documentation, 2021

Figure 3

Counseling About The Role Of Libraries and Study Literary

The result of this stage is the formation of a village library; although it is still not perfect, at least it can attract the interest of school-age children and the wider community to read and come to the library. Some of the counseling participants were even inspired to read several books related to managing regional potentials to be highly competitive. Based on the implementation of service activities carried out for three months in Apuai village, the possible results obtained from this service can be seen in the following table.
Table 1

Result Potential of Communities Services Program

\begin{tabular}{|c|c|c|}
\hline No & Scope & Result Potential \\
\hline \multirow{3}{*}{1} & \multirow{3}{*}{ Education } & $\begin{array}{l}\text { Make it easier for people to get } \\
\text { knowledge through the library }\end{array}$ \\
\hline & & Cultivate reading interest \\
\hline & & Increase Knowledge \\
\hline 2 & Social & $\begin{array}{l}\text { The sustainability of the library in } \\
\text { the village of Apuai agar } \\
\text { people have broad insight by } \\
\text { reading. }\end{array}$ \\
\hline 3 & Economic & $\begin{array}{l}\text { Through literature studies, the } \\
\text { community can recognize the local } \\
\text { potential of the village and manage } \\
\text { it into goods and services that have } \\
\text { better selling power }\end{array}$ \\
\hline
\end{tabular}

Based on the results obtained in the community service program, we plan to implement the program by introducing and using a digital library that can be used offline, considering the difficulty of getting an internet network in Apuai Village. In addition, we will also provide training for library managers to use databases in managing libraries to be more organized and offer laptop facilities to support these activities and increase the collection of books in the Apuai Village library.

\section{CONCLUSIONS}

In this community services activity, we have succeeded in establishing a village library named "Library Manbaul Ulum" identical to the school's name where this library is located. In addition, we have also conducted counseling on the role of libraries to school-age children to increase their interest in reading and educate the public regarding literature studies to improve their welfare. This service is carried out in this village because of the lack of information and knowledge of Apuai Village's people. This library is expected to answer their need for relevant and valuable reading materials.

This community service activity can be continued for other writers with the further use of digital applications for the Apuai Village library, which can be accessed offline due to the absence of an internet signal in this village, and training to use databases in library management. This 
community service can also be applied in other villages that still do not have a reading garden or library in their village, especially for villages that have difficulty getting access to improve their knowledge and insight. For village officials, it is hoped that this library can become an important asset to enhance human resources in the village so that it must be adequately managed.

\section{ACKNOWLEDGMENT}

We thank for Achmad Yani University Banjarmasin; Chancellor of Achmad Yani University Banjarmasin; Dean of the Faculty of Economics, Achmad Yani University; Student Association of Economics and Development Studies, Achmad Yani University Banjarmasin; Apuai Village Government, Aranio District, Banjar Regency, South Kalimantan Province; Doctoral Program in Economics, Universitas Brawijaya; Communities and Donors who have donated books and funds for all assistance in terms of material, energy and thoughts so that community service activities and article writing can be carried out correctly.

\section{DISCLOSURE OF CONFLICTS OF INTEREST}

The authors declare no conflict of interest.

\section{FUND RESOURCING}

The author receives funding support for implementing community service, the writing and/or publication of this article from Achmad Yani Banjarmasin University, and donations from the wider community.

\section{BIBLIOGRAPHY}

Badan Pusat Statistik Kabupaten Banjar. (2020). Jumlah Penduduk Berdasarkan Desa di Kabupaten Banjar.

Badan Pusat Statistik Kabupaten Banjar. (2020). Luas Wilayah Berdasarkan Batas Desa di Kabupaten Banjar.

Darmono. (2016). Manajemen Pelayanan Perpustakaan Desa. Makalah pada Kegiatan Koordinasi Pengembangan Budaya Baca Bimtek Kader Pustaka se Kabupaten Malang 2016, Malang.
Kurnianingsih, Indah, dkk. (2020, Juli). PKM Smart Village Melalui Pengelolaan Perpustakaan Desa Rintisan Berbasis Teknologi Informasi Di Desa Bantarsari Bogor. Jurnal Pengabdian Nusantara, 4 (1). https://doi.org/10.29407/ja.v4i1.13981.

Lasa HS. (2007). Manajemen Perpustakaan Sekolah. Yogyakarta: Pinus Book Publisher.

Pandapotan, Sihar. (2017). Pengembangan Model Kampung Literasi Untuk Meningkatkan Motivasi Pendidikan Dan Minat Membaca Masyarakat Desa Kolam Kab. Deli Serdang.Seminar Nasional Pengabdian Kepada Masyarakat Universitas Terbuka. https://ojs.uma.ac.id/in dex.php/pelitamasyarakat/article/view/3575

Purwanto, Nurtanio Agus. (2006). Kontribusi Pendidikan Bagi Pembangunan Ekonomi Negara. Jurnal Manajemen Pendidikan, 2 (2). https:// media.neliti.com/media/publications/114 456-kontribusi-pendidikan-bagipembangunan-e.pdf

Rohman, Erwina, And Lusiana. (2018). Transformasi Perpustakaan Desa Untuk Peningkatan Kualitas Hidup Masyarakat Pedesaan Di Kabupaten Majalengka. Jurnal Pengabdian Kepada Masyarakat, 2 (12). http://jurnal.unpad.ac.id/pkm /article/view/ 2026.

Sari, Milna. (2020). Dinas PUPR Banjar Akan Bangun Jembatan Hubungkan Tiga Desa di Kecamatan Aranio. Tribunbanjar.com. https://banjarmasin.tribunnews.com/2020/09 /05/dinas-pupr-banjar-akan-bangun-jembata n-hubungkan-tiga-desa-di-kecamatan-aranio Saepuddin, Encang. (2017) Praktik literasi informasi dalam proses pembelajaran sepanjang hayat (information literacy practices in the process of lifelong learning). Jurnal Kajian Informasi \& Perpustakaan 5 (1), 79-94.

Yusup, P., \& Syaeppudin, E. (2017, Juli ). Nilai-nilai Praktis Perpustakaan Desa dan Perpustakaan Masyarakat di Jawa Barat. Record And Library Journal, 3(2). https://ejournal.unair.ac.id/RLJ/article/dow nload/7336/4437 